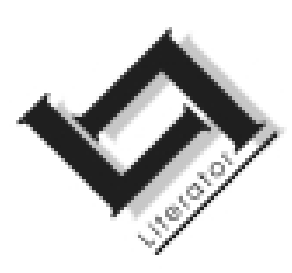

\title{
The modern city: A symbolic space of memory and a crucible for multiculturalism?
}

\author{
Joris Vlasselaers \\ Institute for Cultural Studies \\ Katholieke Universiteit Leuven \\ Leuven \\ E-mail: joris.vlasselaers@arts.kuleuven.ac.be
}

\author{
Abstract \\ The modern city: A symbolic space of memory and a crucible for \\ multiculturalism?
}

This article highlights some critical remarks concerning the use of the terms multiculturalism and cultural identity in various currents of contemporary discourse. The focus will be on the modern metropolis Brussels which will serve as a case study. Brussels is the capital of Belgium and of the European Union and is one of the most distinctly international and multiethnic cities in Europe. In this multicultural society, characterized by the coexistence of groups with different linguistic and cultural traditions, the phenomenon of multi-sociality, i.e. the fact that individuals simultaneously take part in several social subsystems, may neutralize and even overrule cultural or ethnic differences. When it comes to the access of relatively prominent social positions, social differences appear to be of more importance than cultural or ethnic-cultural differences. The question thus remains how to cope with the notion of cultural identity. Second-and third-generation immigrants raising the issue of cultural identity, generally refer to contrastive markers. Culture is conceived of as a package: the differences are articulated as culture, while what is shared with 'outsiders' (especially material culture, science, technology and daily routines) seems to be irrelevant. The city builds a cultural superstructure submitted to an uninterrupted process of change. The ethnic factor is very attractive because people want to experience a community to which they "really" belong and where they can express themselves. The younger generations, however, gradually step out of the strategies of self-protective isolation and advance towards a moderate cultural relativism. In this respect the irrational and affective dimensions of culture, as well as the spatial and social urban fabric, constitute elements of major importance for a close analysis of ethnic-cultural diversity and inequalities. 
The aim of this paper is to call into question the all too casual recourse to the concepts and labels multiculturalism and cultural identity characterising various currents in contemporary discourse.

I shall focus on Brussels as a modern metropolis and use it as a case study to bring forward my critical remarks and annotations. For my basic documentary evidence I mainly draw on research projects undertaken by members of

- IPSoM: Instituut voor Politieke Sociologie en Methodologie at the K.U. Brussels and

- the Centre for Interculturalism and Migration Research and the Institute for Cultural Studies, both at the K.U. Leuven.

\section{Brussels: Capital of Belgium and the European Union}

There is no denying that today Brussels is one of the most distinctly international and multi-ethnic cities in Europe: close on $40 \%$ of its roughly one million residents are of non-Belgian origin. It is the pride of Brussels, "capital of Europe", to function as the host town for numerous international organizations and institutions such as the E.U. (European Parliament and the European Commission with a plethora of committees and an immense administration) and NATO, to name only the most prominent ones. In addition, a steadily increasing number of multinational enterprises and companies locate their European headquarters in Brussels. Alongside this phenomenon, Brussels also harbours an exceptionally large diplomatic colony since most countries have a triple delegation there, accredited respectively at the Belgian nation-state, the E.U. and NATO. This affluence of international political and economic centres as well as forums entails the presence of more than eight hundred officially accredited foreign journalists and reporters, who transform Brussels into the second press centre in the world, running Washington a close second.

So far for "the bright side of the street", because the concentration of working class immigrants (a large majority coming from Morocco and Turkey) in deprived inner-city areas is higher in Brussels than in most other European cities, not to mention an estimated number of 60000 illegal residents (les sans-papiers). Nearly all of them live in an urban patchwork of 127 downgraded streets and quarters in the historic heart of the city and not in the prosperous residential outskirts of the agglomeration.

On the political-governmental level the Belgian nation-state manifests a complex asymmetric federal structure. It consists of three "communities" 
founded on a linguistic basis (the Flemish [60\%], the French [(38\%] and the Germanophone [1\%] communities). These "communities" are in charge of "person-related matters" such as education, culture and healthcare. Apart from the "communities", Belgium also has three so-called regions (Flanders, Wallonia and the region Brussels-Capital) assuming responsibility and authority in the fields of economy, finance and environmental planning.

Brussels forms a distinct urban district (= "region") with an officially bilingual and bicultural (French and Dutch [Flemish]) regime that relies on a strict legal and juridical basis. Belonging to one of the cultural communities is not a matter of territorial definition (native area) or genealogical lineage, but is founded on a free choice. Officially and legally both languages and cultures are equivalent, but the social and communicative reality is different. Since the creation of the Belgian nation-state in 1830 the Francophone bourgeoisie and establishment have exerted strong social pressure on the Dutchspeaking citizens, a situation that finally and in various respects turned Brussels into a preponderantly Francophone city.

Hence the social, cultural and even political insertion of E.U. and nonEuropean immigrants or residents inscribes itself into an already considerable tradition of linguistic-cultural (respectively social-economic) disputes and conflicts. The relatively new arrivals enter into an ethnically divided field that is strongly marked by a discourse based upon the cultural construction of the notion primordial autochtony. This notion stands for the principle that grants special qualifications to individuals and groups in relation to a territorium because these individuals have descended from parents (or ancestors) who lived on that soil first. Legally and juridically Belgium is a non-hierarchic, multi-ethnonational state showing a diversity of cultural programmes of different origin. Although they share a lot of common social knowledge and values the different groups use ethnical markers to specify and position themselves in daily praxis. Notwithstanding the increasing globalisation some referential elements seem to maintain a recurrent and quasi self-evident status: territoriality; primacy (usually linked to the issue of territory); history (a legitimistic representation of the past); descent and proper established modes of symbolisation and communication (language, etc.) (Roosens, 1998:11-16).

\section{Multiculturality and multisociality}

Roland Posner has articulated a triple characterization of culture as a society, i.e. a set of individuals whose mutual relations are organized in specific social institutions; as a civilization, i.e. a set of artefacts that are 
produced and used by the members of this society; and as a mentality (a system of values and ideas, morals and customs), i.e. a set of conventions that control the social institutions and determine the functions and meanings of the artefacts (Posner, 1991:121-123). This definition indicates that in the concept of multicultural society many more elements arise than in the notion culture as it is mostly used in the discourses of literature and the arts.

The term multicultural society is often applied to characterize the coexistence of groups with different languages and different cultural traditions within the state of one nation's territory. Society is not a homogeneous unity. It comprises an aggregate of similarities and differences constituting a social system in which individuals share common sets of reality constructs which they handle through processes and procedures of communication and interaction (Hejl, 1993:229-230). Thus society offers a puzzlingly pluralized field of various perspectives, utterances, attitudes and interaction. Different societal spheres generate different views on a given society and on our modes of participation in it. This phenomenon of multisociality, i.e. the occupying of different social positions, may neutralize and even to a certain extent overrule cultural or ethnic differences. Cultural differences do not entirely correspond with the major societal differences that occur in a society. Individuals take part in and are simultaneously essential to several social subsystems. Hejl states that individuals interact only according to specific reality constructs as components of the social system they participate in. He also argues that some parts of the cultural share and tradition are transformed into the reality constructs of particular social systems. Social subsystems play an important stabilizing part in the construction of culture as a network of socially constructed realities:

Culture can be seen as a domain of generalized knowledge that members of a society probably take to be essentially consistent. It is not understood as a kind of a program, but as a network whose extension and state of elaboration are not clearly known (Hejl, 1993: 242).

Regarding the situation in Brussels a clear distinction should be drawn on the one hand between E.U.- and non E.U.-foreigners, and on the other hand (in both groups), between mostly unskilled immigrant workers and their families and the moneyed middle and upper classes. Well-off citizens from EU-countries, e.g. the European officials and civil servants, can stay and work in Belgian territory and still continue to be French, Dutch, Spanish, etcetera without any restriction. They are freely and in full rights entitled to identify themselves as if they were locals on the basis of their nationality, ethnic or regional extraction, or by virtue of their 
language. They may even succeed in imposing the use of their own or another "international" language.

This logic of inclusion functions like a logic of exclusion when it affects the situation of immigrants from non E.U.-countries. These immigrants are denied the rights to live in Belgian territory as equals. They are tolerated, even protected, but they are not equals. This situation results in the creation of social stereotypes applicable to ethnic minorities. It is indeed remarkable how the young immigrants almost always label themselves as ethnic minority and never as an ethnic group when they participate in debates or interviews. When it comes to the access to more or less prominent positions in the societal landscape cultural differences in sensu stricto do matter, but social differences mostly appear to be of more weight than cultural or ethnic-cultural differences. In the actual balance of power, the ideology of multiculturalism is an advantage for the local "national" populations and the socially and economically stronger allochtones. The vulnerable and powerless allochtones are put at a disadvantage in all respects. The higher their social-economic position or status, the more they can hold to their language and traditional culture in the host country. In social discourse a distinction is made between national minorities (including E.U.-citizens), who are actually considered and treated as autochtones and ethnic minorities, the allochtones (especially the North-Africans and the Turcs) (Kymlicka, 1995). The term multicultural society turns out to refer to a complex totality of power balance, changing values and shifting symbolizations of origin and homeland. It functions as a euphemistic label for a pursuit of equality within a multi-ethnic nation state and society.

\section{Cultural identity and ethnic identity}

How then to cope with the notion of cultural identity within an alleged multicultural environment? Identity does not coincide either with homogeneity or with permanence. A complex tension between "remaining the same over the course of time" for one thing and "changing over time" for another typifies a person's awareness of his identity.

On the level of the self, the individual, the notion of identity is basically linked to its dynamic, constructive and context-bound nature: the self as a system of mutually related selfrepresentations, and a set of relations with others and the world. Individual identity always gives evidence of its social dimension: it is inextricably committed to social identity. Or to use Paul Ricoeur's phrasing: the other exists in ourselves (Ricoeur, 1990:35142). 
Groups, in the sense of accumulations of individuals, also develop a specific group identity that is built upon the sociality dimension in interpersonal relations.

The identity of a community exceeds individuals and groups in space and time. It can be understood as a more abstract form of identity in which personal relations and physical presence or nearness are pushed into the background.

One particular form of community identity is called ethnicity. Hutchinson and Smith (1996:28-34) see at least four main constitutive elements for the establishment of an ethnic entity:

- a name to identify the essence of the community: a label with temporal and changeable symbolic functionality, e.g. to mark territorial borderlines;

- a myth of common descent appealing to common ancestors and a shared cultural tradition;

- collective memories, mental pictures and a common past leading to a popular genealogy and obsessive representations of a partly mythical origin and past. Such constructions may be of decisive importance for the views and attitudes of the parents with regard to their children (e.g. the fear to "lose" their posterity to the host land);

- an odd bond between a real homeland (where they have not necessarily lived) and a symbolic country of the ancestors: a kind of communal experience and historical recollections build a plot, an extended narrative, that strategically allows them to bridge internal differences inside the own community. They locate their roots somewhere else and use this alliance as a basis for mutual solidarity and auto-identification.

According to reports and interviews collected in the research projects I mentioned above, young immigrants of the second and third generations frequently raise the issue of identity, but doing so they mostly refer to a limited number of cultural particularities which they use as contrastive markers. Associating identity with culture in that way makes both terms interchangeable and may stimulate an attitude in which a particular subjective culture is considered to be as absolute as biological and familial uniqueness. Culture is then thought of as a package, clearly distinctive from other cultures. In particular the differences are articulated as culture, while what is shared with "outsiders" (especially the so-called material culture and daily routines, including technology and sciences) seems to be irrelevant. Social promotion often compels the second and 
third generation allochtones to abandon a number of their own domestic cultural schemata, but may as well require that some traditional cultural features are brought in full daylight to function as border-markers. In this way these young allochtones practise a social positioning that comes very near to a populist form of auto-exoticism, a fascination with cultural distinctness Joep Leerssen characterized as "the adoption [...] of an exoticist reputation abroad; the interiorization of such a self-image; and the concomitant adoption and enshrinement of that image's inherent exoticism" (Leerssen, 1992:119). Groups that project themselves as ethnic entities within a society draw a social borderline between themselves ("we") and the others. Cultural differences are no real causal elements, but rather function as secondary factors for identity consciousness. A social cultural borderline only gets its ethnic hallmark when the references to the origin are dominant. The fact is that ethnic groups view themselves as changeless, whereas their culture is in continuous evolution: ethnic identity is experienced as an element of the intimate self. There seems to be a disproportion between the quantity of objective culture one disposes of and the commotion raised around the subjective "own" culture and the rights that are claimed for it.

\section{The city as a cultural and ethnic superstructure}

The city constitutes a cultural superstructure submitted to an uninterrupted process of change and development. For the period of modernity the city meant a key issue and was characterized as a well organized web of coordinates, a functional mobility system, manifesting a clearly outlined distinction between uptown and downtown. The postmodern city, on the contrary, is generally perceived as a place of leisure and consumerism and as a multicentred cosmopolis with radically remodelled social textures and employment patterns. Contemporary urban structures appear to be more than ever framed in the socio-semiotic contradiction between place and space, i.e. place as a space to which a shared meaning has been attributed and thus functioning as a settled and ineluctable cultural condition. Precisely the correlation space - place as a physical condition to organize and accustom social relations, habits and traditions - has considerably faded in the present big cities and has lost much of its modelling potential.

Brussels is a case in point: it is culturally and socially disseminated and the identification of many of its inhabitants with their city (capital of the nation, capital of Europe or simply temporary and provisional hometown) as the public sphere in which they should feel at home becomes complicated. A paramount orientation towards ethnicity generates a feeling of security and social cultural coherence and solidarity among the 
allochtone minorities and may further challenge their already reduced prospects of identification offered by the metropolis. The attractiveness of the ethnic factor is comprehensible: people experience a community to which they really "belong" and in which they can shape their views and habits. According to both the mentioned research projects, the second and third generations gradually step out of the strategies of absolute selfprotective isolation and grow more conscious of the versatility of the traditionally practised systems of signification and valuation. This evolution means a first step on their way to a moderate cultural relativism. But whoever has been educated and socialized in an environment that advances a considerable number of absolute values, has to handle the experience of destabilization, alienation and vulnerability before they are able to regard culture as a primordially intersubjective symbolic system based upon a dialectic between internalizing and externalizing. As a matter of fact, culture as an intersubjective and interactive process of symbolization offers broadening orientations towards the individual self, the others, the material and intellectual worlds and possibly a suprahuman reality. It manifests itself as an aggregate of scripts and schemata that generate patterns of predictability and expectations concerning reality. Signification is thus a process running on different modi and subcultures, all of them marked by deviant and even contradictory representations and practices.

Cultural complexity precisely relies on the social organization of meaning: at any moment larger parts of one's subjective culture exist in the others and the external world, articulated in various discursive formations and material artefacts. Communication plays a cardinal role in these dialectics of internalizing and externalizing. Mass media and the biotopes of the cosmopolitan megapolis account to a large extent for the shared "culture" in contemporary multi-ethnic societies, especially in the fields of material, scientific and technologic culture.

The irrational and affective dimensions of culture also require a close analysis. Cultural or subcultural issues can never be approached apart from the aspect of interpersonal relations because numerous behavioural patterns and standards have already been acquired from childhood. The result is an affective association of certain cultural elements with beloved individuals. This phenomenon lies at the basis of the affective and personalized dimension in the processes of cultural acquisition and preservation. Social economic pressure (getting a job or promotion, social or professional acceptability, etc.) often leads to ambivalent attitudes related to the manifestation or hiding of distinctive cultural features. Even strategies of recuperation are sometimes set up due to overcompensation and overacting. It particularly occurs when under- 
estimation or disdain towards the parental culture manifested by others is experienced, even in those cases where a substantial social and cultural distance between the parents and their children has already been established. Especially religious and social ritualized practices (e.g. in connection with birth, marriage and death, but also related to etiquette in general) that transcend the areas of material and technological culture tend to preserve an irrational basis. They afford some kind of immunity against criticism and misjudgement from the outside, an attitude which of course does not facilitate social admission and cultural integration in the society of the host country.

The spatial and social urban fabric may serve as a laboratory for the investigation of ethnic-cultural diversity and inequalities. The analysis of the physical location and the socio-geographical mapping is of important informative value in this respect because the bond with the street, area or quarter where people live, often develops into an irrational reflex of territorialism, bearing some guarantee of taking roots and public consciousness. For the autochtones the mythologized and monumentalized urban spaces are embedded in the collective memory and narrative of their community. They represent a patrimony of "lieux de mémoire" to use Pierre Nora's terminology (Nora, 1997). These places of memory are the materialization of historical recollections in which a commemorative consciousness subsists in historicizing institutions, celebrations, emblems and symbols, libraries, musea, official edifices, etc. They establish the iconization and hallowing of what are proclaimed to be the cultural heritage and identity of that community. For the allochtones, however, these sites are "non lieux", places with little or no symbolic value and do not have an integrated function in their daily existence. From this perspective we can understand their territorial reflex as a form of symbolic resistance against attempts at forced and alienating assimilation.

What we usually qualify as the multicultural society, is - if not in essence, certainly to a considerable extent - to be located on the level of what the French sociologist Michel Maffesoli has termed "la puissance souterraine", referring to that subterraneous power with its "vouloir vivre" that he estimates to be characteristic of daily life in huge urban populations these days. It is the realm of "la socialite" (opposed to the rigid structures of "la société"). It builds an erotic potential, a collective desire that finds its expression in the incessant stream of people in the streets and their flashing eyes, trivial words and every-day gestures that lie at the basis of authentic coexistence (Maffesoli, 1988:99-110). The increasing impact of "la socialité" in societal life in the postmodern megapolis appears to confirm that the logic of the "organic community" ("la 
tribalisation" Maffesoli would say) is on its way to regain its vitality challenging the "mechanische Gesellschaft" (Max Weber) of modernity.

\section{Bibliography}

Hejl, P.M. 1993. Culture as a Network of Socially Constructed Realities. In: Rigney, A. \& Fokkema, D. (eds.) Cultural Participation. Amsterdam : Benjamins. p. 228250.

Hutchinson, J. \& Smith, A. (eds.) 1996. Ethnicity. Oxford/New York : Oxford University Press.

Kymlicka, W. 1995. Multicultural Citizenship: A Liberal Theory of Minority Rights. Oxford: Clarendon.

Leerssen, J. 1992. Identity and Self-Image: German Auto-Exoticism as Escape from History. In: Dyserinck, H. \& Syndram, K.U. (Hrsg.) Komparatistik und Europaforschung: Prespektiven Vergleichender Literatur- und Kulturwissenschaft. Bonn/Berlin : Bouvier. p. 117-135.

Maffesoli, M. 1988. Le temps des tribus: le déclin de l'individualisme dans les sociétés de masse. Paris : Méridiens-Klinksieck.

Nora, P. 1997 Les lieux de mémoire. Paris : Gallimard.

Posner, R. 1991. Society, civilization, mentality: Prolegomenon to a language policy for Europe. In: Coulmas, F. (ed.) A Language Policy for the European Community. Berlin/New York : Mouton \& De Gruyter. p. 121-137.

Roosens, E. 1998. Eigen grond eerst? Leuven : ACCO.

Ricoeur, P. 1990. Soi-Même comme un Autre. Paris : Seuil.

\section{Key concepts:}

cultural identity

Cultural Studies

culture: the study of

ethnicity

multiculturalism

urban semiotics

\section{Kernbegrippe:}

etnisiteit

kultuur: die bestudering van

kulturele identiteit

Kultuurstudie

multikulturalisme

stedelike semiotiek 